\title{
Uptake, Translocation, and Metabolic Fate of the Herbicide Molinate in Plants
}

\author{
Yasufumi ImaI* and Shozo Kuwatsuka \\ Laboratory of Soil Science, Faculty of Agriculture, Nagoya University, \\ Chikusa-ku, Nagoya 464, Japan
}

(Received August 10, 1983)

\begin{abstract}
Uptake, translocation and metabolic fate of ${ }^{14} \mathrm{C}$-molinate ( $S$-ethylperhydro-2-14 $C$-azepin1-carbothioate) in rice plants and barnyardgrass were studied in the laboratory. Molinate was absorbed through the roots and the basal parts of the shoots by both plants. Greater amounts of molinate were absorbed by barnyardgrass than by rice plants in every case. Although the radioactivity was translocated into whole plants when ${ }^{14} \mathrm{C}$-molinate was absorbed through the roots by both plants, the radioactivity moved only acropetally in rice plants and both acropetally and basepetally in barnyardgrass when ${ }^{14} \mathrm{C}$-molinate was absorbed through the basal parts of the shoots. Organo-extractable metabolites, molinate sulfoxide, azepine ring-4-OH-, -2-oxo-, and -4-oxo- derivatives, $S$ - $\beta$-hydroxyethyl derivative, hexamethyleneimine (HMI), 4-OH-HMI, 2-oxo-HMI, $S$-carboxymethyl derivative, and $S$-ethyl$N$-carboxymethyl thiocarbamate were identified by TLC. The compounds other than sulfoxide and 2 kinds of oxo-derivatives were also found in conjugated forms. Degradation of molinate was more rapid in barnyardgrass than in rice plants. Although molinate was degraded predominantly through the same pathways in barnyardgrass as in rice plants, there were greater amounts of conjugates derived from the basic metabolites, presumably imine compounds, in barnyardgrass, while most of the conjugates were derived from acidic and/or neutral metabolites in rice plants. Most portion of these conjugates was found to be glucosides in rice plants, but a few in barnyardgrass. Possible mechanisms of the herbicidal selectivity between rice plants and barnyardgrass were attributed to the difference in the metabolic products and in the direction of translocation of molinate between both plants.
\end{abstract}

\section{INTRODUCTION}

The herbicide molinate (S-ethyl perhydroazepin-1-carbothioate) has been widely used to control barnyardgrass in paddy rice fields in recent years.

Concerning the behavior of molinate in the environment, studies on its photodegradation and volatilization, ${ }^{1)}$ persistence in paddy fields ${ }^{2,3)}$ and paddy water, ${ }^{4)}$ and degradation in soils ${ }^{5)}$ have already been reported. The authors also reported the degradation in soils

* Present address: Chemicals Development Laboratory, Asahi Chemical Industry Co., Ltd., Yako, Kawasaki-ku, Kawasaki 210, Japan. in the previous paper. ${ }^{6)}$ Its behavior in plants has also been reported..$^{7,8)}$ Chem et al. ${ }^{7}$ reported that leaf-applied ${ }^{14} \mathrm{C}$-molinate was predominantly translocated acropetally in both rice plants and barnyardgrass, whereas rootapplied molinate was translocated into the whole plant in both plants. Uptake of molinate by various kinds of excised organs from barnyardgrass is greater than by those from rice plants. Gray et al.$^{8)}$ reported that ${ }^{14} C$-molinate labelled at the azepine ring or ethyl moiety applied to rice roots was metabolized rapidly. In both cases, ${ }^{14} \mathrm{CO}_{2}$ was evolved and the radioactivity was also found in several amino acids and organic acids in the plants. However, any detailed study on the metabolic pathways 
of molinate in plants have not yet been reported.

In the present report, uptake, translocation, and metabolic fate of molinate in rice plants and barnyardgrass are described.

\section{MATERIALS AND METHODS}

\section{Radioactive Molinate}

Ring $-{ }^{14} \mathrm{C}$-molinate $\left(S\right.$-ethyl perhydro- $2-{ }^{14} \mathrm{C}$ azepin-1-carbothioate) was synthesized by Radiochemical Centre, Amersham, UK, and supplied for this study by Asahi Chemical Industry Co., Ltd. Its radiochemical purity was $98 \%$ and the specific activity was 12.7 $\mathrm{mCi} / \mathrm{mmol}$. It was diluted with non-labelled molinate in ethanol to the concentration of $0.5 \mathrm{mg} / \mathrm{ml}$ and the radioactivity of $3.23 \times 10^{-3}$ $\mathrm{mCi} / \mathrm{ml}$ and used in these experiments.

\section{Reference Compounds}

$S$-Ethyl $N$-(5-carboxypentyl) thiocarbamate (CPET), mp $84.8^{\circ} \mathrm{C}$, was synthesized according to Soderquist et al. ${ }^{1)}$ Modifying their method, $S$-ethyl $N$-carboxymethylthiocarbamate (CMET), mp $81.3^{\circ} \mathrm{C}$; $S$-ethyl $N$-(2-carboxyethyl)thiocarbamate (CETT), mp $87.4^{\circ} \mathrm{C} ; S$ ethyl $\mathrm{N}$-(3-carboxypropyl)thiocarbamate (CPRT), mp $80.4^{\circ} \mathrm{C}$; S-ethyl $N$-(4-carboxybutyl)thiocarbamate (CBUT), $\mathrm{mp} 95.2^{\circ} \mathrm{C}$, were synthesized using glycine, $\beta$-alanine, $\gamma$-amino$n$-butyric acid, and $\delta$-amino- $n$-valeric acid, respectively. $S$-Ethyl $N, N$-(4-oxo-hexamethylene)thiocarbamate (4-oxo-molinate) was obtained as a degradation product of molinate in soil and purified by thin layer chromatography (TLC). ${ }^{6)}$ The chemical structure of these compounds was confirmed by MS and NMR. Other reference compounds were described in our previous paper. ${ }^{6)}$

\section{Plants}

Seeds of rice plants (Oryza sativa L. cultivar Mutsunishiki) and barnyardgrass (Echinochloa crus-galli var. orizacol Ohwi) were allowed to germinate and grow in Kasugai's nutrient solution $\left[\left(\mathrm{NH}_{4}\right)_{2} \mathrm{SO}_{4} 189 \mathrm{mg}, \mathrm{Na}_{2} \mathrm{HPO}_{4} \cdot 12 \mathrm{H}_{2} \mathrm{O}\right.$ $101 \mathrm{mg}, \mathrm{KCl} 47.6 \mathrm{mg}, \mathrm{CaCl}_{2} \cdot 2 \mathrm{H}_{2} \mathrm{O} 10.5 \mathrm{mg}$, $\mathrm{MgCl}_{2} \cdot 6 \mathrm{H}_{2} \mathrm{O} \quad 30.2 \mathrm{mg}, \quad \mathrm{FeCl}_{3} \cdot 6 \mathrm{H}_{2} \mathrm{O} 16.9 \mathrm{mg} / \mathrm{l}$, $\mathrm{pH}$ 5.5-6.0]. The seedlings were harvested at 3- to 3.5-leaf stage and used for the experiments. Cultivation and treatments of the seedlings were carried out in a green house $\left(25-35^{\circ} \mathrm{C}\right)$.

\section{Uptake and Translocation of Molinate}

4.1 Root application with different concentrations of molinate

The roots of rice plants or barnyardgrass were soaked in $20 \mathrm{ml}$ of the nutrient solution containing different concentrations of ${ }^{14} \mathrm{C}$ molinate in each test tube $(2.2 \mathrm{~cm}$ i.d.) for $2 \mathrm{hr}$.

\subsection{Comparison among different types of ap- plications}

Rice plants and barnyardgrass were treated with ${ }^{14} \mathrm{C}$-molinate in several manners. (1) Water culture, root application: Only the roots of the seedlings were soaked in $20 \mathrm{ml}$ of the culture solution containing ${ }^{14} \mathrm{C}$-molinate (10 ppm) in the test tubes. (2) Water culture, application through root and basal part of shoot: The seedlings were transplanted into $20 \mathrm{ml}$ of ${ }^{14} \mathrm{C}$-molinate $(10 \mathrm{ppm})$ in the test tube as mesocotyls were placed $1.5 \mathrm{~cm}$ deep. (3) Soil culture, ${ }^{14} \mathrm{C}$-molinate incorporation into soil: Ten grams of air-dried fine Anjo soil (diluvial soil, kaolinite clay mineral, SCL, clay content $23.1 \%, \mathrm{pH}\left(\mathrm{H}_{2} \mathrm{O}\right) 5.4$, total carbon $1.96 \%$, total nitrogen $0.142 \%$, C.E.C. $10.0 \mathrm{mEq} / 100 \mathrm{~g}$, MWHC $56.3 \%$ ) was mixed with $20 \mathrm{ml}$ of aqueous ${ }^{14} \mathrm{C}$-molinate solution $(10 \mathrm{ppm})$ in the test tube. The seedlings were transplanted into the soil, where the mesocotyls were placed on the surface of the soil. (4) Soil culture, dripping of ${ }^{14} \mathrm{C}$-molinate into flooded water: The seedlings were transplanted into the soil previously flooded with $20 \mathrm{ml}$ of water in the same manner as in (3). Ethanol solution containing $200 \mathrm{mg}$ of ${ }^{14} \mathrm{C}$-molinate was dripped into flooded water. In each of these experiments, 5 seedlings were treated in each test tube.

After certain periods of culture, the seedlings were harvested, washed successively with water and acetone. The seedlings were dried by putting them among several sheets of filter paper for several days. They were divided into roots and shoots and the radioactivity in each part was measured by wet combustion method. ${ }^{6)}$

The radioactivity in the culture solution $[(1),(2)]$ or in the supernatant after centrifuga- 
tion $(1600 \times g, 15 \mathrm{~min})$ of flooded water [(3), (4)] was also measured. The radioactivity in the soil was measured as described previously. ${ }^{6)}$

\section{Metabolic Fate of Molinate in Plants}

5.1 Metabolic fate in rice plants (1)-Balance of radioactivity

The roots of 20 rice seedlings were soaked in $50 \mathrm{ml}$ of the nutrient solution containing ${ }^{14} \mathrm{C}$ molinate $(11.5 \mathrm{ppm})$ in a $100 \mathrm{ml}$ tall beaker. The mouth of the beaker was covered with plastic film, Parafilm ${ }^{\circledR}$, to prevent volatilization of ${ }^{14} \mathrm{C}$-compounds from the solution. Ten seedlings were radioassayed at the end of 2 day-treatment, while the other 10 seedlings were rinsed with water and grown again in the molinate-free nutrient solution for 5 days and radioassayed thereafter. During these treatments, the seedlings were placed in a sealed glass vessel $(3500 \mathrm{ml})$. This vessel was aerated at the rate of $80 \mathrm{ml} / \mathrm{min}$ and the discharged air was led through polyurethane foam, then into $10 \mathrm{~N} \mathrm{NaOH}$ aq. to trap volatile ${ }^{14} \mathrm{C}$ compounds and ${ }^{14} \mathrm{CO}_{2}$, respectively. The trapping foam and solution were renewed every day. The former was washed with $n$-hexane, and the washing solution was radioassayed. The latter was radioassayed using an alkaline scintillator.

5.2 Metabolic fate in rice plants (2)-Time course of ${ }^{14} \mathrm{C}$-compounds in rice plants

Roots of 100 rice seedlings were soaked in $80 \mathrm{ml}$ of the ${ }^{14} \mathrm{C}$-molinate solution (10 ppm) in a $200 \mathrm{ml}$ tall beaker and allowed to absorb ${ }^{14} \mathrm{C}$-molinate for $48 \mathrm{hr}$. The seedlings were washed with water and divided into groups of 15 seedlings and each of them was grown again in the molinate-free solution. After designated periods, the seedlings were subjected to an analytical procedure described later.

\subsection{Comparison of metabolic fate of molinate} between rice plants and barnyardgrass

The roots of 15 rice seedlings or 20 barnyardgrass seedlings were soaked into the ${ }^{14} \mathrm{C}$ molinate solution $(10 \mathrm{ppm})$ in a $50 \mathrm{ml}$ tall beaker for $48 \mathrm{hr}$ and then radioassayed as described below.

\section{Radioassay of ${ }^{14} \mathrm{C}$-Compounds in Plants}

The seedlings were harvested after certain periods of the experiment, washed with water, acetone, and water, successively, and divided into shoots and roots. Each of the parts was chopped and homogenized with tenfold amounts of $70 \%$ aqueous acetone in a Warling blender. The homogenate was filtered through filter paper (Toyo No. 3). The fibrous residue on the filter paper was subjected to the same procedure again and then radioassayed by the wet combustion method. ${ }^{6}$ ) The filtrates were combined, added with same amount of water, extracted with $n$-hexane, ether, and again with ether after $\mathrm{pH}$ was adjusted to 10 , and then with ether after $\mathrm{pH}$ was adjusted to 1 , successively. A small aliquot of each fraction was radioassayed. Most portion of each organoextract fraction was dried with $\mathrm{Na}_{2} \mathrm{SO}_{4}$, concentrated, and subjected to TLC.

\section{Hydrolysis of Aqueous Residue Fraction}

The aqueous residue fraction remaining after extraction with organic solvents was concentrated under reduced pressure to eliminate the remaining acetone, and then hydrolyzed through two ways as in the following:

1) The solution $(15 \mathrm{ml})$ was made to $1 \mathrm{~N}$ $\mathrm{HCl}$ solution and then heated in an ampoule at $120^{\circ} \mathrm{C}$ for $2 \mathrm{hr}$. After cooling, the solution was extracted with ether. The aqueous portion was adjusted to $\mathrm{pH} 10$ with $\mathrm{NaOH}$, and extracted again with ether. Each of the extracts was concentrated and radioassayed by TLC.

2) The solution $(15 \mathrm{ml})$ was adjusted to pH 5 with $1 \mathrm{~N} \mathrm{NaOH}$, and then the $0.2 \mathrm{mg}(12$ units) of $\beta$-glucosidase (Sigma Chemical Co.) was added. This solution was incubated at $37^{\circ} \mathrm{C}$ for $48 \mathrm{hr}$, extracted with ether at $\mathrm{pH} 1$, and then at $\mathrm{pH} \mathrm{10}$, same as above. The ether extracts were radioassayed by TLC.

\section{Thin Layer Chromatography (TLC)}

${ }^{14} \mathrm{C}$-Compounds in the organo-extracts were radioassayed by co-chromatography with standard compounds as described in the previous report. ${ }^{6)} R f$ values of the newly synthesized compounds were shown in Table 1.

\section{Radioassay}

Radioassay in each solution and the wet combustion procedure were carried out as described previously. ${ }^{6)}$ 
Table $1 R f$ values of authentic compounds ${ }^{a}$ ) on thin layer chromatogram.

\begin{tabular}{lcccc}
\hline & \multicolumn{5}{c}{ Solvent system $^{\mathrm{c}}$ (ompounds } \\
& $\mathrm{A}$ ) & $\mathrm{B}$ & $\mathrm{C}$ & $\mathrm{H}$ \\
\cline { 2 - 5 } & 0.74 & 0.78 & 0.90 & 0.79 \\
Molinate & 0.45 & 0.35 & - & - \\
4-oxo-Molinate & 0.09 & 0.06 & 0.15 & 0.40 \\
CMET & 0.17 & 0.12 & 0.21 & 0.44 \\
CETT & 0.26 & 0.12 & 0.24 & 0.45 \\
CPRT & 0.30 & 0.12 & 0.26 & 0.47 \\
CBUT & 0.29 & 0.13 & 0.29 & 0.52 \\
CPET & &
\end{tabular}

a) $R f$ values of the other authentic compounds were reported previously. ${ }^{6}$

b) The chemical names are shown in the text.

c) Solvent systems; A : ether-toluene $(7: 3 \mathrm{v} / \mathrm{v})$, $\mathrm{B}$ : isooctane-dioxane $(2: 1 \mathrm{v} / \mathrm{v}), \mathrm{C}$ : benzeneacetone-acetic acid $(19: 1: 2 \mathrm{v} / \mathrm{v}), \mathrm{H}: n$-hexane-ethyl acetate-formic acid $(30: 30: 1 \mathrm{v} / \mathrm{v})$.

\section{RESULTS}

\section{Uptake and Translocation in Plants}

As shown in Fig. 1, barnyardgrass absorbed greater amounts of ${ }^{14} \mathrm{C}$-molinate than rice plants at any concentration when the roots were soaked in the molinate solution for $2 \mathrm{hr}$. With increasing the molinate concentration, radioactivity in the roots increased in both plants. Radioactivity in the shoots, however, increased in proportion to that in the roots only in barnyardgrass but changed scarcely in rice plants.

Uptake and translocation of molinate by both plants under different conditions in water and soil cultures are shown in Fig. 2. Barnyardgrass always absorbed greater amounts of molinate than rice plants. When the roots and the basal parts of the shoots were soaked in the molinate solution (2), radioactivity in the shoots was greater in comparison with when only the roots were soaked (1), for both plants. This difference was quite noticeable in barn-

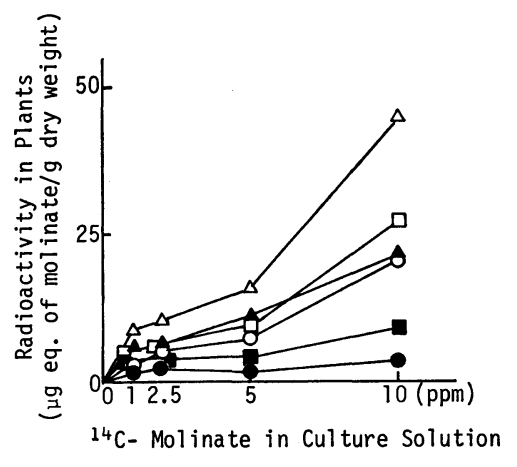

Fig. 1 Relationship between molinate concentration in culture solution and absorption by rice plants and barnyardgrass.

Riceplants; $\mathbf{\square}$ : whole plant, $\bullet$ : shoot, $\Delta$ : root.

Barnyardgrass; $\square$ : whole plant, $\bigcirc$ : shoot, $\triangle$ : root.

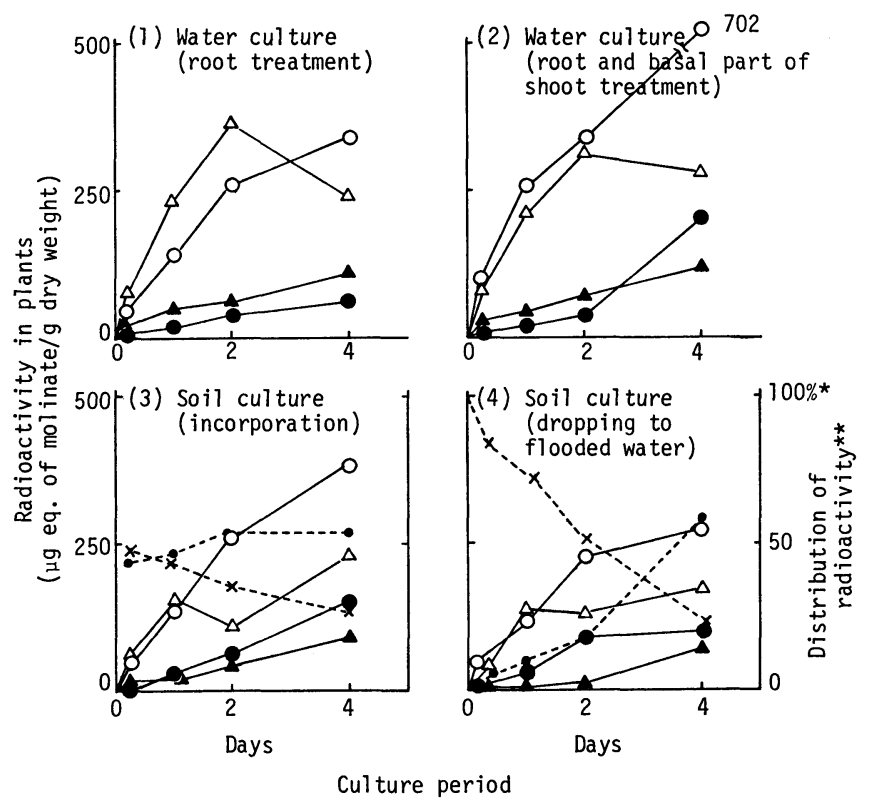

Fig. 2 Absorption of molinate by rice plants and barnyardgrass under various culture conditions.

Radioactivity in plants; 0 : rice plant shoot, $\mathbf{\Delta}$ : root. Barnyardgrass; $O$ : shoot, $\triangle$ : root. Distribution of radioactivity; - : soil, $x$ : flooded water.

* $\%$ of total radioactivity treated, ** values were got during the cultivation of rice plants. 
yardgrass and the radioactivity in the shoots of barnyardgrass was 4 times more than that of rice plants. The absorption was somewhat smaller in both plants when molinate was incorporated into the soil (3), compared to water culture (2). When molinate was dripped into flooded water (4), it was adsorbed rapidly to the soil. In this case, radioactivity was detected both in the roots and the shoots in barnyardgrass from $6 \mathrm{hr}$ after the dripping. In rice plants, however, radioactivity was detected only in the shoots from $6 \mathrm{hr}$, but was scarcely detected in the roots until 2 days later when great amounts of radioactivity were detected in the soil as well.

\section{Metabolic Fate of Molinate}

Exp. I Metabolic fate in rice plants (1)-Balance of radioactivity

Rice seedlings absorbed 7\% of the applied radioactivity for $48 \mathrm{hr}$, when their roots were soaked in the ${ }^{14} \mathrm{C}$-molinate solution in the closed system (Table 2).

During the following 5 days after the seedlings were transplanted into the molinate-free solution, only a small part of radioactivity disappeared as ${ }^{14} \mathrm{CO}_{2}$ and other volatile compounds, while about $60 \%$ of the absorbed radioactivity was released from the roots into the culture solution, and $30 \%$ remained in the seedlings.

The radioactivity in the seedlings was equivalent to 47 and $179 \mathrm{ppm}$ of molinate (dry

Table 2 Loss of radioactivity from rice plants root-treated with ${ }^{14} \mathrm{C}$-molinate.

\begin{tabular}{lcc}
\hline & $\begin{array}{c}\text { After root- } \\
\text { treatment with } \\
14 C \text {-molinate } \\
\text { for 2 days }\end{array}$ & $\begin{array}{c}\text { After cultiva- } \\
\text { tion in moli- } \\
\text { nate-free } \\
\text { solution for } \\
5 \text { days }^{\mathrm{b} \text { ) }}\end{array}$ \\
\hline Plants & $7.1 \%$ & $31.6 \%$ \\
${ }^{14} \mathrm{CO}_{2}$ & 0.2 & 7.7 \\
Volatilized & 0.03 & 1.2 \\
Culture solution & 92.7 & 59.4 \\
(remaining) & (released) \\
\hline
\end{tabular}

a) Values are expressed by percentage of radioactivity to total ractivity treated.

b) Values are expressed by percentage of radioactivity to that in the seedlings after roottreatment for 2 days. weight base) in the shoots and the roots, respectively, after $48 \mathrm{hr}$-absorption. These values decreased to 20 and $43 \mathrm{ppm}$ during the following 5 days cultivation period without molinate. The decrease in the roots was remarkable.

Exp. II Metabolic fate in rice plants (2)-Time course of ${ }^{14} \mathrm{C}$-compounds

When the roots of rice seedlings were soaked in the ${ }^{14} \mathrm{C}$-molinate solution for $48 \mathrm{hr}$, then allowed to grow in the molinate-free solution, nearly $50 \%$ of the radioactivity in the seedlings was fractionated into the aqueous residue fraction (organo-unextractable fraction). This proportion increased to a constant level 1 day after transplanting. Simultaneously, the portion of radioactivity in the organo-extractable fractions decreased and that in the fibrous residue increased (Fig. 3, Table 3).

Most of the radioactivity in $n$-hexane and/or neutral ether extracts was attributed to molinate in the roots. In the shoots, however, the ratio of ${ }^{14} \mathrm{C}$-molinate to the total radioactivity was small, while the ratios of the organo-extractable degradation products, the aqueous residue, and the fibrous residue were large (Table 3).

Twenty to twenty-five percent of the radioactivity in the aqueous residue fraction was extracted into ether after hydrolysis with $\mathrm{HCl}$, and 6 to $10 \%$ after hydrolysis with $\beta$-glucosidase. Most of this ether extractable radioactivity was attributed to neutral and/or

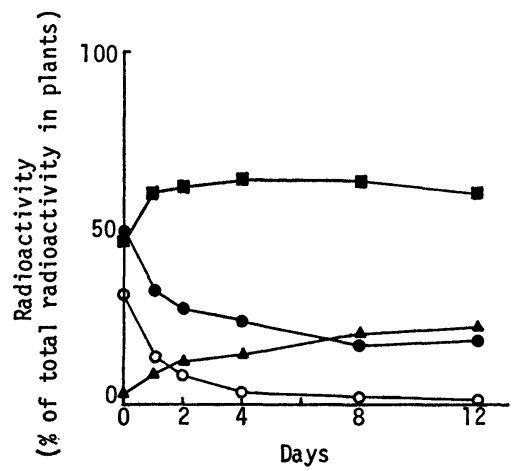

Fig. 3 Changes in radioactivity of fractions from rice plants after transplanting.

$\bigcirc$ : molinate, $\bullet$ : organo-extractable fractions,

$\mathbf{\square}$ : aqueous residue, $\boldsymbol{\Delta}$ : fibrous residue. 
Table 3 Changes in radioactivity in extract fractions from rice plants root-treated with ${ }^{14} \mathrm{C}$-molinate.

$(\%)^{\text {a) }}$

\begin{tabular}{|c|c|c|c|c|c|c|c|c|}
\hline \multirow{2}{*}{ Plant part } & \multirow{2}{*}{$\begin{array}{l}\text { Days after } \\
\text { trans- } \\
\left.\text { planting }{ }^{b}\right)\end{array}$} & \multicolumn{6}{|c|}{$70 \%$ Aqueous acetone extract } & \multirow{2}{*}{$\begin{array}{l}\text { Fibrous } \\
\text { residue }\end{array}$} \\
\hline & & $n$-Hexane & $\begin{array}{l}\text { Neutral } \\
\text { ether }\end{array}$ & $\begin{array}{l}\text { Basic } \\
\text { ether }\end{array}$ & $\begin{array}{l}\text { Acidic } \\
\text { ether }\end{array}$ & $\begin{array}{l}\text { Aqueous } \\
\text { residue }\end{array}$ & Molinate & \\
\hline \multirow[t]{6}{*}{ Shoot } & 0 & 9.7 & 4.8 & 2.0 & 5.0 & 39.7 & 5.9 & 2.9 \\
\hline & 1 & 2.2 & 3.2 & 4.7 & 7.2 & 53.2 & 0.4 & 6.7 \\
\hline & 2 & 2.7 & 3.8 & 5.4 & 7.0 & 53.6 & 0.4 & 9.5 \\
\hline & 4 & 2.2 & 3.4 & 6.7 & 6.3 & 56.9 & 0.2 & 11.8 \\
\hline & 8 & 1.4 & 2.3 & 5.6 & 4.4 & 56.2 & 0.4 & 17.0 \\
\hline & 12 & 3.6 & 2.2 & 6.3 & 4.0 & 53.6 & 0.2 & 18.0 \\
\hline \multirow[t]{6}{*}{ Root } & 0 & 25.2 & 1.8 & 0.3 & 0.5 & 6.9 & 26.0 & 1.0 \\
\hline & 1 & 12.7 & 0.1 & 0.5 & 0.3 & 7.2 & 12.6 & 1.9 \\
\hline & 2 & 7.4 & 0.2 & 0.4 & 0.5 & 7.4 & 7.2 & 2.1 \\
\hline & 4 & 4.4 & 0.3 & 0.7 & 0.3 & 6.5 & 3.9 & 2.0 \\
\hline & 8 & 1.8 & 0.1 & 0.7 & 0.3 & 7.2 & 1.6 & 2.7 \\
\hline & 12 & 0.7 & 0.1 & 0.5 & 0.2 & 6.8 & 0.4 & 4.1 \\
\hline Culture solution & 12 & 21.9 & 24.0 & 7.7 & 3.3 & 43.1 & 9.7 & - \\
\hline
\end{tabular}

a) Values are expressed by percentage of radioactivity to total radioactivity in plants or in culture solution.

b) The roots of rice seedlings were soaked in ${ }^{14} \mathrm{C}$-molinate solution for $48 \mathrm{hr}$ and transplanted into molinate-free culture solution.
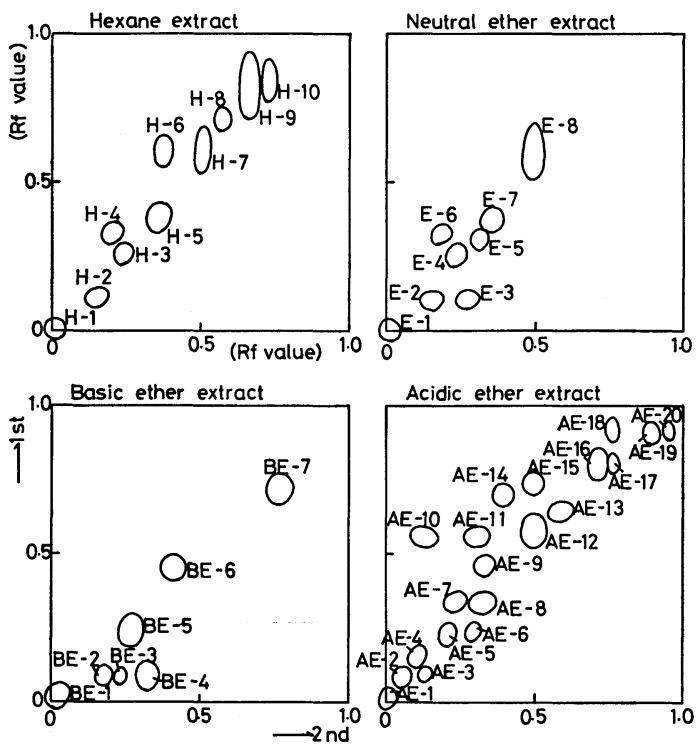

Fig. 4 Thin layer chromatograms of organoextracts.

Each extract was developed with the same solvent systems.

1st (vertical): ether-toluene $(7: 3 \mathrm{v} / \mathrm{v}), 2$ nd (horizontal): isooctane-dioxane $(2: 1 \mathrm{v} / \mathrm{v})$.

$\mathrm{H}-2$ : molinate-sulfoxide, $\mathrm{H}-3$ : 4-OH-molinate, $\mathrm{H}-5$ : 4-oxo-molinate, H-7: 2-oxo-molinate, H-9: molinate, $\mathrm{H}-1,-4,-6,-8,-10$ : unknown, E-1: including HMI, E-2: molinate-sulfoxide, E-4: 4-OHmolinate, E-5: molinate-alcohol, E-7: 4-oxomolinate, E-8: 2-oxo-molinate, E-3,-6: unknown, BE-1: including HMI, BE-2: 4-OH-HMI, BE-4 : 2-oxo-HMI, BE-3, -5, -6, -7: unknown, AE-2: CMET, AE-4: molinate-acid, AE-1, $-3,-5 \sim-20$ : unknown. acidic compounds, and less than a tenth of that of basic ones. The proportion of each of these neutral and/or acidic fraction and basic fraction to the aqueous residue was almost identical in the roots and the shoots and did not increase or decrease significantly for 12 days. Six percent of the radioactivity in the aqueous residue fractionated from the nutrient solution in which molinate-treated rice seedlings were grown for 12 days was also extracted with ether after $\mathrm{HCl}$-hydrolysis.

Many radioactive spots were detected on the TLC plates of every organo-extractable fraction, as shown in Fig. 4. The following 
Table 4 Molinate and its metabolites in organo-extractable fractions from rice plants roottreated with ${ }^{14} \mathrm{C}$-molinate.

$(\%)^{\text {a) }}$

\begin{tabular}{|c|c|c|c|c|c|c|c|c|}
\hline \multirow{2}{*}{ Compounds } & \multirow{2}{*}{$\begin{array}{l}\text { Spot No. } \\
\text { in Fig. } 5\end{array}$} & \multirow{2}{*}{$\begin{array}{l}\text { Plant } \\
\text { part }^{\text {b) }}\end{array}$} & \multicolumn{6}{|c|}{ Days after transplanting } \\
\hline & & & 0 & 1 & 2 & 4 & 8 & 12 \\
\hline Molinate & $\mathrm{H}-9$ & $\begin{array}{l}\mathrm{S} \\
\mathrm{R}\end{array}$ & $\begin{array}{r}5.9 \\
24.2\end{array}$ & $\begin{array}{r}0.4 \\
12.5\end{array}$ & $\begin{array}{l}0.4 \\
7.1\end{array}$ & $\begin{array}{l}0.2 \\
3.8\end{array}$ & $\begin{array}{l}0.4 \\
1.6\end{array}$ & $\begin{array}{l}0.2 \\
0.4\end{array}$ \\
\hline 4-OH-Molinate & $\mathrm{H}-3 \& \mathrm{E}-4$ & $\begin{array}{l}\mathrm{S} \\
\mathrm{R}\end{array}$ & $\begin{array}{l}1.6 \\
0.9\end{array}$ & $\begin{array}{l}0.8 \\
\text { tr. }\end{array}$ & $\begin{array}{l}0.6 \\
0.1\end{array}$ & $\begin{array}{l}0.9 \\
\text { tr. }\end{array}$ & $\begin{array}{l}0.3 \\
\text { tr. }\end{array}$ & $\begin{array}{l}0.5 \\
0.1\end{array}$ \\
\hline 4-oxo-Molinate & H-5 \& E-7 & $\begin{array}{l}\mathrm{S} \\
\mathrm{R}\end{array}$ & $\begin{array}{l}2.1 \\
0.7\end{array}$ & $\begin{array}{l}1.2 \\
0.1\end{array}$ & $\begin{array}{l}1.1 \\
0.1\end{array}$ & $\begin{array}{l}0.9 \\
0.1\end{array}$ & $\begin{array}{l}0.4 \\
0.1\end{array}$ & $\begin{array}{l}0.6 \\
\text { tr. }\end{array}$ \\
\hline 2-oxo-Molinate & H-7 \& E-8 & $\begin{array}{l}\mathrm{S} \\
\mathrm{R}\end{array}$ & $\begin{array}{l}1.2 \\
0.2\end{array}$ & $\begin{array}{l}0.5 \\
\text { tr. }\end{array}$ & $\begin{array}{l}0.5 \\
0.1\end{array}$ & $\begin{array}{l}0.5 \\
0.5\end{array}$ & $\begin{array}{l}0.6 \\
\text { tr. }\end{array}$ & $\begin{array}{l}0.6 \\
0.1\end{array}$ \\
\hline Molinate-alcohol & E-5 & $\begin{array}{l}\mathrm{S} \\
\mathrm{R}\end{array}$ & $\begin{array}{l}0.2 \\
\text { N.D. }\end{array}$ & $\begin{array}{l}1.0 \\
\text { tr. }\end{array}$ & $\begin{array}{l}0.1 \\
\text { tr. }\end{array}$ & $\begin{array}{l}1.0 \\
\text { tr. }\end{array}$ & $\begin{array}{l}0.5 \\
\text { tr. }\end{array}$ & $\begin{array}{l}0.4 \\
\text { tr. }\end{array}$ \\
\hline Molinate-sulfoxide & $\mathrm{H}-2$ \& E-2 & $\begin{array}{l}\mathrm{S} \\
\mathrm{R}\end{array}$ & $\begin{array}{l}0.2 \\
0.2\end{array}$ & $\begin{array}{l}\text { N.D. } \\
0.1\end{array}$ & $\begin{array}{l}\text { tr. } \\
0.1\end{array}$ & $\begin{array}{l}\text { N.D. } \\
0.1\end{array}$ & $\begin{array}{l}0.2 \\
\text { tr. }\end{array}$ & $\begin{array}{l}0.2 \\
\text { tr. }\end{array}$ \\
\hline Molinate-acid & AE-4 & $\begin{array}{l}\mathrm{S} \\
\mathrm{R}\end{array}$ & $\begin{array}{l}0.2 \\
0.1\end{array}$ & $\begin{array}{l}0.2 \\
\text { N.D. }\end{array}$ & $\begin{array}{l}0.1 \\
0.1\end{array}$ & $\begin{array}{l}0.1 \\
\text { tr. }\end{array}$ & $\begin{array}{l}0.1 \\
\text { N.D. }\end{array}$ & $\begin{array}{l}0.1 \\
\text { N.D. }\end{array}$ \\
\hline CMET & AE-2 & $\begin{array}{l}\mathrm{S} \\
\mathrm{R}\end{array}$ & $\begin{array}{l}0.3 \\
0.1\end{array}$ & $\begin{array}{l}0.3 \\
0.1\end{array}$ & $\begin{array}{l}0.2 \\
\text { tr. }\end{array}$ & $\begin{array}{l}0.1 \\
\text { tr. }\end{array}$ & $\begin{array}{l}0.1 \\
\text { tr. }\end{array}$ & $\begin{array}{l}0.1 \\
\text { tr. }\end{array}$ \\
\hline HMI & $(\mathrm{E}-\mathrm{I} \& \mathrm{BE}-1)$ & $\begin{array}{l}\mathrm{S} \\
\mathrm{R}\end{array}$ & $\begin{array}{l}0.1 \\
\text { tr. }\end{array}$ & $\begin{array}{l}0.3 \\
\text { tr. }\end{array}$ & $\begin{array}{l}0.2 \\
\text { tr. }\end{array}$ & $\begin{array}{l}0.4 \\
\text { tr. }\end{array}$ & $\begin{array}{l}0.2 \\
\text { tr. }\end{array}$ & $\begin{array}{l}0.3 \\
\text { tr. }\end{array}$ \\
\hline 2-oxo-HMI & $\mathrm{BE}-4$ & $\begin{array}{l}\mathrm{S} \\
\mathrm{R}\end{array}$ & $\begin{array}{l}\text { tr. } \\
\text { tr. }\end{array}$ & $\begin{array}{l}\operatorname{tr} . \\
\operatorname{tr} .\end{array}$ & $\begin{array}{l}\text { tr. } \\
\text { tr. }\end{array}$ & $\begin{array}{l}\text { tr. } \\
\text { tr. }\end{array}$ & $\begin{array}{l}\text { tr. } \\
\text { tr. }\end{array}$ & $\begin{array}{l}\text { tr. } \\
\text { tr. }\end{array}$ \\
\hline 4-OH-HMI & $\mathrm{BE}-2$ & $\begin{array}{l}\mathrm{S} \\
\mathrm{R}\end{array}$ & $\begin{array}{l}\text { tr. } \\
\text { tr. }\end{array}$ & $\begin{array}{l}\text { tr. } \\
\text { tr. }\end{array}$ & $\begin{array}{l}\text { tr. } \\
\text { tr. }\end{array}$ & $\begin{array}{l}\text { tr. } \\
\text { tr. }\end{array}$ & $\begin{array}{l}\text { tr. } \\
\text { tr. }\end{array}$ & $\begin{array}{l}\text { tr. } \\
\text { tr. }\end{array}$ \\
\hline
\end{tabular}

a) Values are expressed by percentage of radioactivity of each compound to total radioactivity in plants.

b) S: shoot, R: root.

Table 5 Ether-extractable compounds after hydrolysis of aqueous residues of rice plants ${ }^{a}$ ) with $\mathrm{HCl}$ or $\beta$-glucosidase.

\begin{tabular}{|c|c|c|c|c|c|}
\hline \multirow{2}{*}{ Compounds } & \multicolumn{3}{|c|}{ Shoot } & \multicolumn{2}{|c|}{ Root } \\
\hline & Treatment & $\mathrm{HCl}$ & $\beta$-Glucosidase & $\mathrm{HCl}$ & $\beta$-Glucosidase \\
\hline \multicolumn{6}{|c|}{ Neutral and acidic substances } \\
\hline 4-OH-Molinate & & 2.7 & 1.5 & 0.3 & tr. \\
\hline Molinate-alcohol & & 3.1 & 1.2 & 0.5 & tr. \\
\hline CMET & & 1.0 & 0.4 & 0.1 & N.D. \\
\hline Molinate-acid & & N.D. & N.D. & 0.1 & 0.1 \\
\hline Others & & 4.4 & 2.8 & 0.3 & 0.5 \\
\hline \multicolumn{6}{|l|}{ Basic substances } \\
\hline HMI & & $\operatorname{tr}$. & N.D. & N.D. & N.D. \\
\hline 2-oxo-HMI & & tr. & tr. & tr. & $\operatorname{tr}$ \\
\hline 4-OH-HMI & & $\operatorname{tr}$ & tr. & tr. & $\operatorname{tr}$ \\
\hline Others & & 1.8 & 1.2 & tr. & 0.1 \\
\hline Total & & 13.0 & 7.1 & 1.2 & 0.7 \\
\hline
\end{tabular}

a) Rice plants were harvested 12 days after transplanting.

b) Values are expressed by percentage of radioactivity of each compound to total radioactivity in plants. 
compounds were identical with the authentic compounds on TLC with several different solvent systems; in hexane fraction : molinate, its sulfoxide, azepine ring-4-OH-, 4-oxo-, and 2-oxo-derivatives; in neutral ether fraction: $S$ - $\beta$-hydroxyethyl derivative(molinate-alcohol), molinate-sulfoxide, azepine ring-4-OH-, 4-oxoand 2-oxo-derivatives; basic ether fraction: 4-OH-hexamethyleneimine (4-OH-HMI), 2oxo-HMI; in acidic ether fraction: $S$-ethyl- $N$ carboxymethylthiocarbamate (CMET), S-carboxymethyl derivative (molinate-acid). Ten to twenty-five percent of the radioactivity on the original spots of neutral and basic ether extracts was attributed to HMI. Time course of these compounds are shown in Table 4.

Azepine ring-4-OH-derivative, molinatealcohol, CMET, molinate-acid, HMI, 4-OHand 2-oxo-HMI were recognized in conjugated forms in the rice plants (Table 5).

Exp. III Comparison of metabolic fate between rice plants and barnyardgrass

Distribution of radioactive compounds in the seedlings of rice plants and barnyardgrass after $48 \mathrm{hr}$-treatment was shown in Table 6 . Molinate was metabolized more rapidly to produce greater amounts of metabolites in barnyardgrass than in rice plants. The variety of free (not conjugated) metabolites, however, was the same in both plants. In rice plants, radioactivity in the roots was more than that in the shoots and most of it was attributed to ${ }^{14} \mathrm{C}$-molinate. In barnyardgrass, almost the same amount of radioactivity was distributed in the roots and the shoots, and the proportions of the organo-extractable degradation products and the aqueous residue were large even in the roots.

In rice plants, every degradation product was more prevalent in the shoots, while, in barnyardgrass, molinate-alcohol, 4-oxo- and 2-oxo-derivatives were more prevalent in the roots. About $20 \%$ of the radioactivity in the aqueous residue was extracted with ether after $\mathrm{HCl}$-hydrolysis in rice plants, but about $40 \%$ was extracted in barnyardgrass (Table 7). This ether-extractable radioactivity was attributed predominantly to neutral and/or acidic compounds in rice plants but to mostly basic compounds in barnyardgrass. In rice plants, almost the same kind and amount of ${ }^{14} \mathrm{C}$-compounds were extracted after enzymatic hydrolysis and acid hydrolysis of the aqueous residue. This result suggested that these conjugates were almost all glucosides, while in barnyardgrass, only a small amount of ${ }^{14} \mathrm{C}$ -

Table 6 Distribution of radioactivity in plants treated with ${ }^{14} \mathrm{C}$-molinate for $48 \mathrm{hr}$.

$(\%)^{\text {a) }}$

\begin{tabular}{|c|c|c|c|c|}
\hline & \multicolumn{2}{|c|}{ Rice plants } & \multicolumn{2}{|c|}{ Barnyardgrass } \\
\hline & Shoot & Root & Shoot & Root \\
\hline Total & 33.4 & 66.6 & 53.6 & 46.4 \\
\hline Organo-extractable fractions & 16.0 & 60.4 & 13.0 & 22.6 \\
\hline Aqueous residue & 16.5 & 4.8 & 38.2 & 21.9 \\
\hline Fibrous residue & 0.9 & 1.4 & 2.3 & 1.9 \\
\hline Molinate & 8.8 & 58.6 & 0.8 & 12.1 \\
\hline Molinate-sulfoxide & 0.2 & 0.2 & 0.6 & N.D. \\
\hline 4-OH-Molinate & 0.5 & 0.2 & 2.6 & 0.7 \\
\hline Molinate-alcohol & 1.1 & 0.2 & 1.5 & 3.0 \\
\hline 4-oxo-Molinate & 1.5 & 0.4 & 1.7 & 2.7 \\
\hline 2-oxo-Molinate & 0.9 & 0.4 & 1.1 & 2.3 \\
\hline CMET & 0.2 & N.D. & 0.1 & 0.1 \\
\hline Molinate-acid & 0.2 & N.D. & 0.1 & $\operatorname{tr}$ \\
\hline HMI & tr. & tr. & 0.5 & 0.2 \\
\hline 2-oxo-HMI & N.D. & tr. & N.D. & N.D. \\
\hline 4-OH-HMI & $\operatorname{tr}$ & 0.3 & 0.3 & 0.2 \\
\hline
\end{tabular}

a) Values are expressed by percentage of radioactivity to total radioactivity in plants. 
Table 7 Ether-extractable compounds after hydrolysis of aqueous-residue of rice plants and barnyardgrass with $\mathrm{HCl}$ or $\beta$-glucosidase.

$(\%)^{a)}$

\begin{tabular}{|c|c|c|c|c|c|}
\hline \multirow{2}{*}{ Compounds } & \multirow[b]{2}{*}{ Treatment: } & \multicolumn{2}{|c|}{ Rice plants } & \multicolumn{2}{|c|}{ Barnyardgrass } \\
\hline & & $\mathrm{HCl}$ & $\beta$-Glucosidase & $\mathrm{HCl}$ & $\beta$-Glucosidase \\
\hline \multicolumn{6}{|c|}{ Neutral and acidic substances } \\
\hline 4-OH-Molinate & & 0.7 & 1.4 & 2.3 & 0.3 \\
\hline Molinate-alcohol & & 1.7 & 1.1 & 1.7 & 0.2 \\
\hline CMET & & N.D. & $\operatorname{tr}$. & 0.7 & 0.5 \\
\hline Molinate-acid & & N.D. & N.D. & tr. & N.D. \\
\hline Others & & 1.5 & 1.1 & 0.4 & 0.9 \\
\hline \multicolumn{6}{|l|}{ Basic substances } \\
\hline HMI & & N.D. & N.D. & 0.8 & 0.1 \\
\hline 2-oxo-HMI & & tr. & N.D. & 2.6 & 0.2 \\
\hline 4-OH-HMI & & tr. & N.D. & 1.2 & 2.0 \\
\hline Others & & 0.8 & tr. & 13.8 & 1.0 \\
\hline Total & & 4.7 & 3.6 & 23.5 & 5.2 \\
\hline
\end{tabular}

a) Values are expressed by percentage of radioactivity of each compound to total radioactivity in plants.

compounds were extracted after the enzymatic hydrolysis of the aqueous residue, compared to the acid hydrolysis (Table 7).

Total radioactivity absorbed into the seedlings was equivalent to 37.3 and $40.0 \mathrm{ppm}$ of molinate (fresh weight base) in rice plants and barnyardgrass, respectively, while the concentration of molinate was 5.9 and $51.4 \mathrm{ppm}$ in the shoots and the roots of rice plants and 0.5 and $14.2 \mathrm{ppm}$ in the shoots and roots of barnyardgrass, respectively. Barnyardgrass showed smaller values than rice plants.

\section{DISCUSSION}

\section{Uptake and Translocation in Rice Plants and Barnyardgrass}

With increasing molinate concentration in the culture media, radioactivity in the shoots increased in proportion to that in the roots in barnyardgrass only, whereas it scarcely changed in rice plants (Fig. 1). It was, therefore, suggested that the transport of the radioactive compounds was limited in rice plants. On the other hand, barnyardgrass has a great ability to transport ${ }^{14} \mathrm{C}$-molinate and/or its metabolites from roots to shoots. This hypothesis agrees with the results by Chem et al. ${ }^{7}$ that the excised tissues of barnyardgrass absorbed more molinate than did corresponding tissues of rice plants.
Furthermore, in every case, more amount of molinate was absorbed by barnyardgrass than by rice plants (Fig. 2). However, some differences were recognized in the mode of uptake and translocation. When the mesocotyls of seedlings were placed in the molinate solution for planting ((2) in Fig. 2), the shoots of both plants contained more radioactivity than in the case of root treatment (1). This fact showed that the absorption was greater through the basal part of shoots of both plants than through the roots. When molinate was incorporated into the soil (3), the molinate absorption was affected only a little by the soil, which had molinate adsorption coefficient $K_{d}=5.67$. When ${ }^{14} C$-molinate had been applied into flooded water on the surface of soil (4), radioactivity in the roots of rice plants was slight until molinate moved into the soil (2. days after the application), and thereafter, radioactivity in the roots increased correspondingly with the increase of radioactivity in the soil. Thus it is supposed that even such soil with a small absorption co-efficient can be a barrier to molinate movement into the soil and that rice plants can translocate molinate only acropetally but not basepetally. In barnyardgrass, however, molinate is translocated in both directions rapidly from the basal parts of the shoots and entered easily even into the roots. 


\section{Metabolic Fate in Plants}

A large amount of radioactivity was released into the culture solution from the roots of rice plants, when the molinate treated seedlings were transplanted into the molinate-free solution (Tables 2 and 3). Nakamura et al. ${ }^{23)}$ reported that, under sterile conditions, a thiocarbamate herbicide, benthiocarb (thiobencarb), and its metabolites in rice seedlings were easily exuded through the roots into a benthiocarb-free culture solution. Therefore, it was suggested that these compounds moved in and out easily through the cell membrane of rice roots. In our experiments, however, due to the non-sterile conditions, it can not be decided finally whether the metabolites of ${ }^{14} \mathrm{C}$ molinate were released from the seedlings or the metabolites were formed by degrading microbes on the root surface in the culture solution. The former case is more probable because molinate was found continuously in the culture solution for 12 days, and also because the ${ }^{14} \mathrm{C}$-compounds in the culture solution included the conjugated compounds which have never been found in soil degradation ${ }^{5,6}$ or as microbial metabolites in the culture solution $^{20-22)}$ but were easily found in the plants in this study.

Fang and George ${ }^{11)}$ reported that the degradation of a thiocarbamate herbicide, pebulate, is considerably enhanced under high temperature conditions. As shown in Tables 4 and 6, the degradation rates of molinate were greater in the metabolism experiment of Exp. II than in the metabolism experiment of Exp. III, and this probably reflected the temperature difference, because the metabolic experiments of Exp. II and III were carried out at $32-35^{\circ} \mathrm{C}$ and at $28-33^{\circ} \mathrm{C}$, respectively, of room temperatures.

From the organo-extractable metabolites and the ether extractable compounds from the hydrolysates of aqueous residue, the following metabolic pathways are proposed (Fig. 5).

i) The $\mathrm{S}$ atom is oxidized to sulfoxide, and metabolized further to conjugated compounds. A part of the sulfoxide may also be further transformed to HMI probably through the sulfone of molinate.

ii) The Carbon atoms of the azepine ring oxidized to hydroxy derivatives and then to oxo-derivatives. These $\mathrm{OH}-$ or oxo-derivatives are further metabolized to OH-HMI or oxoHMI after oxidation of $\mathrm{S}$ atom and hydrolysis, and to CMET by the fission of the azepine ring.

iii) The end carbon of $S$-ethyl moiety is oxidized to a hydroxy derivative (molinatealcohol) and then to carboxy derivative (molinate acid). These derivatives as well as the imines are evidently conjugated by glucose or other compounds.

In barnyardgrass, in addition to the above described pathways, the sulfoxide and/or the

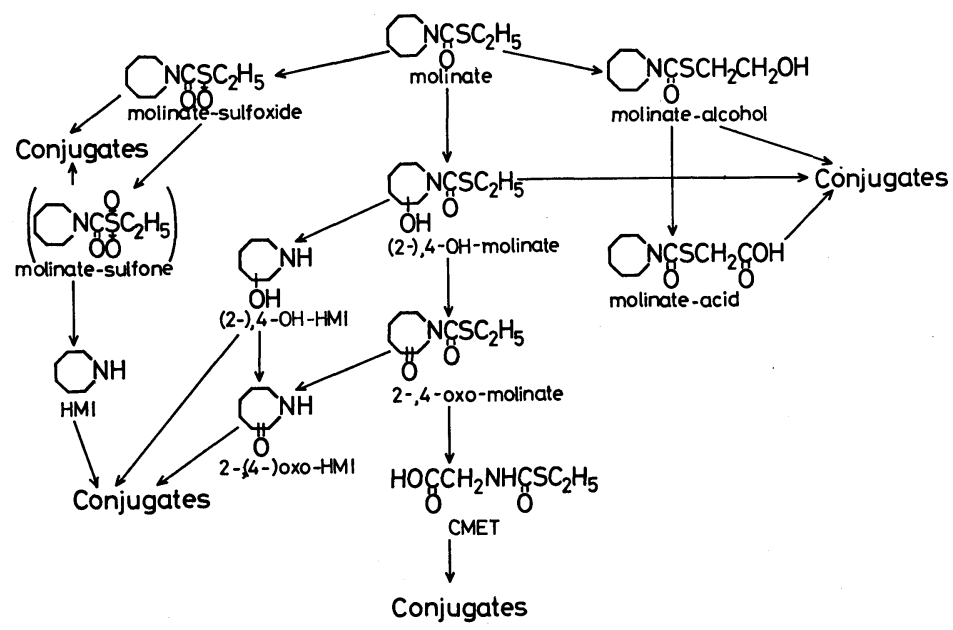

Fig. 5 Possible metabolic pathways of molinate in plants. 
sulfone of molinate and its metabolites may also make a covalent bond with certain kinds of plant materials, which will be discussed later. The water-soluble conjugate metabolites differed largely between rice plants and barnyardgrass, which will also be discussed later concerning the herbicidal selectivity.

It has been reported that the carbon atoms of $N$-alkyl moiety of some thiocarbamate herbicides are finally incorporated into plant constituents, ${ }^{8,12,13)}$ and the sulfoxide formed in plants is conjugated by glutathione and transformed further. ${ }^{14-16)}$ These processes are also possible for molinate metabolism, although we did not confirm it. Although molinate-acid may be formed by the oxidation of $S$-ethyl moiety, the metabolic process through glutathione and cystein conjugates is also possible for molinate-acid formation, as elucidated in EPTC metabolism in rat. ${ }^{14)}$

\section{Comparison with Degradation in Soil}

These metabolic pathways in plants are almost the same as those in soils except for the conjugate formation. ${ }^{6)}$ Acidic metabolites were not detected so many in soil as these were found in plants. A large portion of these compounds which were found in plants are produced in plants, although only a small portion might be produced in soil and absorbed into plants.

\section{Herbicidal Selectivity of Molinate}

Hubbell and Casida ${ }^{14)}$ suggested positive relevance between plant resistance to thiocarbamate herbicides and its degradation rate in the plant. Further, Nakamura et al. ${ }^{10)}$ reported that rice seedlings (resistant) absorbed smaller amount of benthiocarb and metabolized at greater rate than barnyardgrass (susceptible), resulting in lower concentration in rice seedlings than barnyardgrass.

While, in this study, rice plants absorbed less molinate, the degradation rate was smaller so that the concentration in rice seedlings was greater than that in barnyardgrass conversely, when molinate is absorbed through the roots of seedlings.

In barnyardgrass, however, molinate was easily translocated not only acropetally but also basepetally from the basal part of shoots to be distributed in every part of the plant, but it was translocated only acropetally in rice plants, when molinate was applied into flooded water on soil surface. This application method is a practical one in paddy fields. Therefore, this difference in translocation may be one of the mechanisms of herbicidal selectivity of molinate between rice plants and barnyardgrass in paddy fields.

The mode of herbicidal action of thiocarbamates has been postulated, which is due to the sulfoxides or sulfones of the chemicals formed in plants which react by carbamoylation with SH-compounds in the plants. ${ }^{16-19)}$ In this study, only in barnyardgrass, molinate was degraded rapidly to form a large amount of hydrophilic metabolites which were transformed to ether-extractable basic substances by acid hydrolysis as major components (Table 7). This conjugation of the imine may be a detoxication mechanism on one hand, but the prevalent metabolites with imine structure in barnyardgrass may combine with important materials such as $\mathrm{SH}$-enzymes or $\mathrm{SH}$-coenzymes in the plant to exhibit the herbicidal activity to barnyardgrass on the other hand. These hydrophilic compounds could be yielded not only by conjugation with the imines but also by carbamoylation of plant $\mathrm{SH}$-compounds with the imines. On the other hand, in rice plants, those conjugate compounds were hydrolyzed predominantly to ether-extractable neutral or acidic substances with acid and glucosidase. This observation was quite different from the metabolic patterns in barnyardgrass.

\section{ACKNOWLEDGEMENTS}

We wish to express our sincere thanks to Asahi Chemical Industry Co., Ltd. for supplying radioactive and authentic chemicals. We also express our gratitude to Prof. K. Kumada and other members of our laboratory for their invaluable suggestions and encouragement during the course of this study.

\section{REFERENCES}

1) C. J. Soderquist, J. B. Bowers \& D. G. Crosby: J. Agric. Food Chem. 25, 940 (1977)

2) K. K. Tanji, J. W. Bigger, M. Hehran, M. W. Cheung \& D. W. Henderson: Calif. Agric. 28, 10 (1974)

3) L. E. Deuel, F. T. Turner, K. W. Brown \& J. D Price: J. Environ. Qual. 7, 373 (1978) 
4) M. Kato \& S. Maru: Bull. Chiba-ken Agric. Exp. Stn. 19, 127 (1978)

5) V. M. Thomas \& G. L. Holt: J. Environ. Sci. Health B15, 475 (1980)

6) Y. Imai \& S. Kuwatsuka: J. Pesticide Sci. 7, 487 (1982)

7) T. M. Chem, D. E. Seaman \& F. M. Ashton: Weed Sci. 16, 28 (1968)

8) R. A. Gray: Weed Sci. Soc. Am. Abstr. 1969, 174: "Herbicides--Chemistry, Degradation and Mode of Action," 2nd ed., ed. by P. C. Kearney $\&$ D. D. Kaufman, Marcel Dekker, Inc., New York, p. 330, 1975

9) Y. Nakamura, K. Ishikawa \& S. Kuwatsuka: Agric. Biol. Chem. 38, 1129 (1974)

10) Y. Nakamura, K. Ishikawa \& S. Kuwatsuka: Agric. Biol. Chem. 41, 1613 (1977)

11) S. C. Fang \& M. George: Plant Physiol. Suppl. 37, XXVI (1962)

12) F. M. Ashton \& A. S. Crafts: "Mode of Action of Herbicides," 2nd ed., A Wiley-Interscience Publication, New York, p. 314, 1981

13) J. Antognini, R. A. Gray \& J. J. Menn: Proc. Selective Weed Control in Beetcrops, 2nd Int. 1, p. 293,1970

14) J. P. Hubbell \& J. E. Casida: J. Agric. Food Chem. 25, 404 (1977)

15) R. D. Carringer, C. E. Rieck \& L. P. Bush: Weed Sci. 26, 157 (1978)

16) L. Horváth \& A. Pulay: Pestic. Biochem. Physiol. 14, 265 (1980)

17) M. M. Lay \& J. E. Casida: Pestic. Biochem. Physiol. 6, 442 (1976)

18) J. E. Casida, R. A. Gray \& H. Tilles: Science 184, 573 (1974)

19) J. E. Casida, E. C. Kimmel, M. Lay, H. Ohkawa, J. E. Rodebush, R. A. Gray, C K. Tseng \& H. Tilles: Environ. Qual. Saf. Suppl. 3, 675 (1975)

20) L. A. Golovleva, E. L. Golovlev, A. M. Zyakun, Yu. V. Shurukhin \& Z. I. Finrelstein: Izv. Akad. Nauk SSSR Ser. Biol. 1, 44 (1978)
21) G. K. Skryabin, L. A. Golovleva, A. M. Zyakun, V. G. Sakharovskiy, A. L. Klysheva, Iu. V. Shurukhin \& M. Iu. Nefedova: Dokladwi Akad. Nauk SSSR 239, 717 (1978)

22) Y. Imai \& S. Kuwatsuka: Abstract of the 6th Annual Meeting of Pesticide Science Society of Japan, p. 306, 1981 (in Japanese)

23) Y. Nakamura, S. Kuwatsuka \& M. Yatazawa: Weed Res. Jpn. 22, Suppl., 31 (1977) (in Japanese)

要約

\section{除草剤モリネートの植物における吸収・移行 · 代謝}

今井康史, 鍬塚昭三

モリネートのイネおよびヒエによる吸収・移行・代謝 について室内実験で研究した. モリネートはイネおよび ヒエに根部打よび茎葉基部から吸收され，吸収量はイネ よりもヒエのほうが大きかった．根部から吸收されたモ リネートは両植物とも全植物体に移行したが, 菱葉基部 から吸収されたモリネートはイネでは上方移行のみ, ヒ エでは両方向に移行した。イネおよびヒエ体中の有機 溶媒抽出性分解物の TLC 分析により，モリネートスル ホキシド, アゼピン環-4-OH-, -2-oxo- および 4-oxo体， $S$ - $\beta$-ヒドロキシェチル体，4-OH-，2-oxo-抒よび無 置換へキサメチレンイミン打よび $S$-エチルーN-カルボ キシメチルチオカーバメートが同定された. スルホキシ ド体打よび 2 種類のオキソ体以外の化合物は抱合体とし ても存在していた。モリネートのヒエ体内の分解速度は イネよりも速やかであった．分解経路はイネとヒエで差 がなかったが，七エでは塩基性分解物括そらくイミン化 合物の抱合体が多く，イネ体内の抱合体は酸性または中 性物質の抱合体であった。モリネートのイネーヒエ間選 択殺草性は移行と代謝様式の差によるものであろうと推 察した。 